\title{
Study of Antioxidant Activity, Peptides, and Chemical Quality of Goat Milk Kefir on the Different Post- Acidification Periods During Cold Storage
}

\author{
Ahmad Khoirul Umam ${ }^{1,}$ Lilik Eka Radiati ${ }^{1 *}$ Kevin Hutomo Putra Suwondo ${ }^{2}$ and Siti \\ Nur Kholidah $^{2}$ \\ ${ }^{1}$ Lecturer of Animal Product Technology Department, Faculty of Animal Science, Brawijaya University, Malang \\ ${ }^{2}$ Student of Animal Product Technology Department, Faculty of Animal Science, Brawijaya University, Malang \\ ${ }^{*}$ Corresponding author. Email: lilik.eka@ub.ac.id
}

\begin{abstract}
The interaction between raw goat milk, lactic acid bacteria (LAB), and kefir grain resulted in the unique taste and flavor of fermented products. Under optimum temperature, LAB and yeast had the better condition for growth and optimizing metabolic activity. The proportion level of kefir grains should be considered during the incubation period because it could change the logarithmic growth phase of lactic acid bacteria. After the processing, cold storage should be applied to suppress microorganism growth in the post-acidification period. The prolonged post-acidification period potentially affects the quality of Goat milk kefir products. This research aimed to evaluate the effect of a post-acidification period during cold storage based on antioxidant, peptides, and chemical quality of goat milk kefir. The experimental design was a completely randomized design (RCD) with four treatments and three replications. The quality analysis was done in the different post-acidification periods for 1 day, 7 days, 14 days, and 21 days after being stored at $4^{\circ} \mathrm{C}$. Duncan Multiple Range Test (DMRT) was used for further statistical analysis. The results showed that the different postacidification periods had significant effects $(\mathrm{p}<0.05)$ on antioxidant activity, peptide, fat, and ethanol content. On Average, antioxidant activity, peptide, fat, and ethanol content in goat-milk kefir were $55.70 \pm 2.25 \%, 9.32 \pm 0.13 \mathrm{mg}$ / $\mathrm{ml}, 1.86 \pm 0.08 \%$, and $1.04 \pm 0.04 \%$, respectively. In conclusion, the longer period of post-acidification has a major contribution to the change of goat milk kefir characteristics during cold storage.
\end{abstract}

Keywords: Kefir grains, peptide, alcohol, antioxidant.

\section{INTRODUCTION}

Lactic acid bacteria as EPS-producing microorganisms and yeast were combined to provide unique physicochemical characteristics that have been used in fermented products, including kefir [1]. Due to their antioxidant activities, several species of EPSproducing LAB, including Streptococcus, Lactobacillus, Pediococcus, Lactococcus, and Bifidobacterium, has potential probiotic characteristics that could be linked to human health and disease prevention [2]. In addition, certain types of yeast and LAB used in fermented products also resulted in a variety of organic acids, bacteriocins, the molecular weight of the protein, and antimicrobial peptides [3].

LAB and yeast had better growth conditions and could optimize metabolic activity when incubated under their optimum temperature. The proportion level of kefir grains should be considered during the incubation period because it could change the logarithmic growth phase of lactic acid bacteria. After the processing was done, the products should be kept in a cold storage to suppress microorganism growth post-acidification.

However, the post-acidification process might still occur during the storage period related to the microorganism's activity. The post-acidification study is an essential step in determining the shelf stability of fermented products because it is defined as the increase in acidity caused by lactic acid bacteria's continuous production of acids [4]. During storage at $4^{\circ} \mathrm{C}$, postacidification occurred in fermented milk products, lowering the $\mathrm{pH}$ value due to lactic acid bacteria's continuous metabolic activity [5]. 
The prolonged post-acidification period potentially affects the decreasing quality of Goat milk kefir products. This research aimed to study the post-acidification of goat milk kefir according to antioxidant activity, peptides, and chemical quality during 21 days of cold storage

\section{MATERIALS AND METHODS}

\subsection{Material}

Fresh goat milk as raw material was obtained from Madukara Farm, Bumiaji, Batu. Additional equipment used to make kefir included food-grade plastic bottles, incubator, filter, refrigerator, gas stove, food-grade measured glass, thermometer, spoon, and kefir grains.

\subsection{Methods}

The kefir goat milk was manufactured using the following step (1) mixing $3 \mathrm{~g}$ of kefir grains into $100 \mathrm{ml}$ of fresh goat's milk (2) incubating the mixture at room temperature for 24 hours (3) opening and stirring the kefir (4) incubating again at room temperature for 24 hours. All equipment was sterilized, then kefir was harvested and placed in sample bottles at $4^{\circ} \mathrm{C}$. Kefir samples were harvested on $0,7,14,21$ days and were calculated. The content of peptide, fat, alcohol, and the antioxidant percentage were evaluated using NanoDrop One Protein A205, Babcock method, ethanol level assay according to the way of [6], and DPPH assay used the form of [7]. This research method was used a completely randomized design with 4 treatments and 3 replicates. The treatments were divided into different storage times for $0,7,14$, and 21 days. Data were analyzed using ANOVA (Analysis of Variance), and any significant difference effect of the variables measured, followed by Duncan's Multiple Range Test (DMRT).

\section{RESULTS AND DISCUSSION}

\subsection{Peptide}

Peptides, dissolved proteins, lactose, vitamins, and amino acids are chemical molecules found in the supernatant. Physiological and physicochemical milk's peptide is an excellent ingredient to improve health status
[8] so that the higher the peptide, the better the quality of kefir. The results (Table 1) showed that the postacidification period had a highly significant effect $(\mathrm{P}<0.01)$ on the peptide. The peptide content of $\mathrm{T} 3$ was the lowest, with an average of $7.77 \mathrm{mg} / \mathrm{ml}$. The peptide content indicates the dissolved protein of kefir. The protein content of kefir increased with the increasing concentration of kefir grains because kefir grains contain high protein content ranged from $3.10 \%$ to $4.72 \%$ [9]

During Post-acidification, milk protein is hydrolyzed into peptides and amino acids. Protease and peptidase are the enzymes produced by microorganisms that can break down $90 \%$ of peptide bonds. Hydrolysis is influenced by the capability of LAB, especially from the Lactobacillus group in kefir grains which are proteolytic, and it's supported by enzyme availability on the substrate [10]

\subsection{Fat}

Fat is a molecule found in kefir that relates the taste and microorganism activity. According to Codex Standard [11], the fat content of kefir is less than $10 \%$. The results (Table 1) showed that the cold storage treatment has a highly significant effect on the total fat content of kefir $(\mathrm{P}<0.01)$. The $21^{\text {st }}$ day of the postacidification period resulted in the lowest fat content with an average value of $1.17 \% \pm 0.12$. During storage, fat content gradually decreases because fat is one of the main components consumed by lactic acid bacteria and yeast. Fat is one of the main components consumed by lactic acid bacteria and yeast. LAB produces enzymes that hydrolyze fat into fatty acids and glycerol.

This result is in line with [12] that fat content in the kefir optima tended to decrease by $1.7 \% \pm 0.249$ at 48 hours of fermentation. The Post-acidification process will increase lipase that producing from microorganism's growth, which will cause an increase in the hydrolysis of fats and will affect the reduction of the fat content [13]. Kefir's with low-fat content may indicate the fat has been hydrolyzed into molecules that the body can easily digest.

\subsection{Alcohol}

During post-acidification, the alcohol levels have increased due to yeast metabolic activity. According to Table 1, Post-acidification has a highly significant effect

Table 1. The peptides, fat, alcohol, and antioxidants content in goat milk kefir with different fermentation time

\begin{tabular}{|c|c|c|c|c|}
\hline & Peptide $(\mathrm{mg} / \mathrm{ml})$ & Fat $(\%)$ & Alcohol (\%) & Antioxidant \\
\hline T0 & $9.22 \pm 0.05^{\mathrm{b}}$ & $2.52 \pm 0.04^{\mathrm{d}}$ & $0.35 \pm 0.04^{\mathrm{a}}$ & $41.33 \pm 1.52^{\mathrm{a}}$ \\
\hline T1 & $10.34 \pm 0.17^{\mathrm{d}}$ & $2.08 \pm 0.08^{\mathrm{c}}$ & $0.91 \pm 0.03^{\mathrm{b}}$ & $48.27 \pm 2.28^{\mathrm{b}}$ \\
\hline T2 & $9.88 \pm 0.20^{\mathrm{c}}$ & $1.65 \pm 0.08^{\mathrm{b}}$ & $1.08 \pm 0.04^{\mathrm{c}}$ & $59.17 \pm 2.67^{\mathrm{c}}$ \\
\hline T3 & $7.77 \pm 0.11^{\mathrm{a}}$ & $1.17 \pm 0.12^{\mathrm{a}}$ & $1.79 \pm 0.06^{\mathrm{d}}$ & $74.04 \pm 2.51^{\mathrm{d}}$ \\
\hline
\end{tabular}

${ }^{\mathrm{a}-\mathrm{d}}$ Different superscript letters in the same column mean significantly different $(\mathrm{P}<0.01)$. 
$(\mathrm{P}<0.01)$ on the alcohol content. The highest alcohol content was at T3 with the value of $1.79 \% \pm 0.06$, while the lowest alcohol content showed on kefir without cold storage. Based on [14], the alcohol content will increase when fermentation time is prolonged for 14 days of storage $(0.12 \%$ alcohol) then increasing on 21 days of storage $(0.41 \%)$ at $15^{\circ} \mathrm{C}$.

Saccharomyces cerevisiae is a yeast that converts monosaccharides and disaccharides into invertase and zymase enzymes which are useful for converting simple sugars including lactose in goat's milk into ethanol, alcohol, and $\mathrm{CO}_{2}$ [15]. When the $\mathrm{pH}$ is below 4, LAB activity will slightly down. This condition is used by yeast to grow and oxidize glucose so that the alcohol content in kefir increases rapidly.

\subsection{Antioxidant Activity}

Antioxidants can delay or stop other molecules from oxidizing. Oxidation is a chemical process that produces free radicals, which can cause cell damage in a chain reaction. The results (Table 1) showed a highly significant effect $(\mathrm{P}<0.01)$ based on the antioxidant activity, with the highest value was on the 21 st day Postacidification period $(74.04 \pm 2.5)$. The breakdown of proteins into peptides shows an increase in antioxidant activity because most peptide groups have antioxidant properties.

In general, antioxidants also increase along with the increase in the total alcohol content in which there is phenol, the growth is thought to be due to the breakdown of structural compounds such as protein and fat into simpler ones caused by the metabolic activity of lactic bacteria. The increase in antioxidants was followed by a decrease in fat content due to the hydrolysis of fats that occurred by LAB so that the fat bonds were broken into carboxylic acids and glycerol. Carboxylic acid is one of the alcohol groups which is an antioxidant [16]

\section{CONCLUSION}

The post-acidification of goat milk kefir resulted in the highest values observed for peptides on the 7 th day of storage $(10.34 \mathrm{mg} / \mathrm{ml})$. Fat content was gradually decreased during post-acidifications until 21 days. Alcohol percentage and antioxidant activity were observed after 21 days of storage; the increasing probably due to the activity of LAB and Yeast. In conclusion, the more extended period of post-acidification has a significant contribution to the change of goat milk kefir characteristics during cold storage.

\section{ACKNOWLEDGMENTS}

This research was supported by funds and scheme of Research Grand Faculty of Animal Science UB, and we thank Prof. Dr. Ir. Djalal Rosyidi, MS., IPU., ASEAN

Eng. for suggestion on the manuscript.

\section{REFERENCES}

[1] Ismail B, Nampoothiri KM. Production, purification and structural characterization of an exopolysaccharide produced by a probiotic Lactobacillus plantarum MTCC 9510. Archives of Microbiology. 2010 Dec;192(12):1049-57.

[2] Wang J, Zhao X, Tian Z, Yang Y, Yang Z. Characterization of an exopolysaccharide produced by Lactobacillus plantarum YW11 isolated from Tibet Kefir. Carbohydrate Polymers. 2015 Jul 10;125:16-25.

[3] Radiati LE, Umam AK, Susilo A, Thoifi AA. Effect of Lactobacillus plantarum Concentration Level on Physicochemical Properties of Fermented Goat Meat Dendeng. In: IOP Conference Series: Earth and Environmental Science. Institute of Physics Publishing; 2020.

[4] Lourens-Hattingh A, Viljoen BC. Growth and survival of a probiotic yeast in dairy products [Internet]. Available from: www.elsevier.com/locate/foodres

[5] Khoirul Umam A, Lin M-J, Radiati LE, Peng S-Y. The Capability of Canna edulis Ker Starch as Carboxymethyl Cellulose Replacement on Yogurt Drink During Cold Storage. Animal Production. 2018;20(2):109-18.

[6] Ali E, Nielsen SD, Abd-El Aal S, El-Leboudy A, Saleh E, LaPointe G. Use of Mass Spectrometry to Profile Peptides in Whey Protein Isolate Medium Fermented by Lactobacillus helveticus LH-2 and Lactobacillus acidophilus La-5. Frontiers in Nutrition. 2019 Oct 15;6.

[7] Shori AB. Antioxidant activity and viability of lactic acid bacteria in soybean-yogurt made from cow and camel milk. Journal of Taibah University for Science. 2013 Oct;7(4):202-8.

[8] Park YW, Nam MS. Bioactive Peptides in Milk and Dairy Products: A Review. Korean Journal for Food Science of Animal Resources. 2015 Dec 1;35(6):831-40.

[9] Tomar O, Akarca G, Çağlar A, Beykaya M, Gök $\mathrm{V}$. The effects of kefir grain and starter culture on kefir produced from cow and buffalo milk during storage periods. Food Science and Technology. 2020 Jan 1;40(1):238-44.

[10] Kezwoń A, Chromińska I, Fraczyk T, Wojciechowski K. Effect of enzymatic hydrolysis on surface activity and surface rheology of type I 
collagen. Colloids and Surfaces B: Biointerfaces. 2016 Jan 1;137:60-9.

[11] STANDARD FOR FERMENTED MILKS. 2003.

[12] ReguŁa A. Free fatty acid profiles of fermented beverages made from ewe's milk. Lait. 2007 Jan;87(1):71-7.

[13] Konkit M, Kim W. Activities of amylase, proteinase, and lipase enzymes from Lactococcus chungangensis and its application in dairy products. Journal of Dairy Science. $2016 \mathrm{Jul}$ 1;99(7):4999-5007.

[14] Kök-Taş T, Seydim AC, Özer B, Guzel-Seydim ZB. Effects of different fermentation parameters on quality characteristics of kefir. Journal of Dairy Science. 2013 Feb;96(2):780-9.

[15]. Guzel-Seydim Z, Seydim AC, Greene AK. Organic acids and volatile flavor components evolved during refrigerated storage of Kefir. Journal of Dairy Science. 2000;83(2):275-7.

[16] Sohaib M, Anjum FM, Sahar A, Arshad MS, Rahman UU, Imran A, et al. Antioxidant proteins and peptides to enhance the oxidative stability of meat and meat products: A comprehensive review. Vol. 20, International Journal of Food Properties. Taylor and Francis Inc.; 2017. p. 2581-93. 